\title{
Chloroplast DNA variation of white oaks in northern Balkans and in the Carpathian Basin
}

\author{
Sándor Bordács ${ }^{\mathrm{a}, \mathrm{b}, 1}$, Flaviu Popescu ${ }^{\mathrm{c}, \mathrm{d}}$, Danko Slade ${ }^{\mathrm{d}, \mathrm{e}}$, Ulrike M. Csaikl ${ }^{\mathrm{b}}$, \\ Isabelle Lesur ${ }^{\mathrm{d}}$, Attila Borovics ${ }^{\mathrm{f}}$, Pál Kézdy ${ }^{\mathrm{g}}$, Armin O. König ${ }^{\mathrm{h}}$, Dušan Gömöry ${ }^{\mathrm{i}}$, \\ Simon Brewer ${ }^{\mathrm{j}, \mathrm{k}}$, Kornel Burg ${ }^{\mathrm{b}}$, Rémy J. Petit ${ }^{\mathrm{d}}$,* \\ ${ }^{a}$ Department of Forestry, National Institute for Agricultural Quality Control (OMMI), Budapest Keleti K. u. 24. H-1024, Hungary \\ ${ }^{\mathrm{b}}$ Austrian Research Centre Seibersdorf (ARCS), A-2444 Seibersdorf, Austria \\ ${ }^{\mathrm{c}}$ ICAS, Arboretum Simeria, Str. Biscaria 1, 2625 Simeria, Romania \\ ${ }^{\mathrm{d}}$ Institut National de la Recherche Agronomique (INRA), Station de Recherches Forestiéres, BP 45, F-33611 Gazinet Cedex, France \\ ${ }^{\mathrm{e}}$ Forest Research Institute, 10450 Jastrebarsko, Croatia \\ ${ }^{\mathrm{f}}$ Forest Research Institute, Sárvár, Botanic Garden, Várkerület 30/a. H-9600, Hungary \\ ${ }^{\mathrm{g}}$ Department of Botany, University of Sopron, Sopron Ady E. u. 5. H-9400, Hungary \\ ${ }^{\mathrm{h}}$ Bundesforschungsanstalt für Forst- und Holzwirtschaft (BFH), Institut für Forstgenetik und Forstpflanzenzüchtung, Sieker Landstrasse 2, \\ D-22927 Grosshansdorf, Germany \\ ${ }^{\mathrm{i}}$ Faculty of Forestry, Technical University in Zvolen, 96053 Zvolen, Slovak Republic \\ ${ }^{\mathrm{j}}$ IMEP, CNRS UPRES A6116, Faculté de St. Jérôme, case 451, 13397 Marseille Cedex 20, France \\ ${ }^{\mathrm{k}}$ European Pollen Database, Centre Universitaire d'Arles, 13200 Arles, France
}

\begin{abstract}
A total of 1113 oak trees from 222 populations originating from eight countries (Austria, Bosnia-Herzegovina, Croatia, Hungary, Romania, Slovakia, Slovenia, Yugoslavia) were sampled in natural populations or in provenance tests. The sampled trees belong to four different species (Quercus robur, Quercus petraea, Quercus pubescens, Quercus frainetto) and to several putative subspecies. Variation at four chloroplast DNA (cpDNA) fragments was studied using restriction enzymes, resulting in the detection of 12 haplotypes. One haplotype was present in $36 \%$ of the trees, and six were found in 6-17\% of the trees. The haplotypes are shared extensively between species and subspecies. They belong to three different lineages (A, C and E) and are phylogeographically structured in the region investigated. Haplotypes of lineage E dominate to the east of the Carpathian mountains in Romania, whereas the Carpathian Basin seems to have been colonised along several different colonisation routes, from the Balkan peninsula but also from Italy. The data support the possible role of climatic instability during the late glacial period in shaping this complex geographic structure. The presence of several secondary refugia could be inferred in the region, which have played a major role in the second step of recolonisation, at the onset of the Holocene period. (C) 2002 Elsevier Science B.V. All rights reserved.
\end{abstract}

Keywords: Quercus spp.; PCR-RFLP; Postglacial recolonisation; Refugia; Species distribution

\footnotetext{
* Corresponding author. Tel.: +33-557979087; fax: +33-557979088.

E-mail addresses: bordacss@ommi.hu (S. Bordács), remy@ pierroton.inra.fr (R.J. Petit).

${ }^{1}$ Co-corresponding author. Present address: Department of Forestry, National Institute for Agricultural Quality Control (OMMI), Budapest Keleti K. u. 24. H-1024, Hungary. Tel.: +36-1-2124808; fax: +36-1-2125367.
} 
Table 1

Taxa belonging to the Robur group included in this study

\begin{tabular}{|c|c|c|c|c|c|}
\hline \multicolumn{2}{|l|}{ Oak taxon } & \multicolumn{3}{|c|}{ Natural distribution in refugia areas } & \multirow[t]{2}{*}{ Main ecological characters or demands } \\
\hline Species & Related taxa & $\begin{array}{l}\text { Balkan } \\
\text { peninsula }\end{array}$ & $\begin{array}{l}\text { Italian } \\
\text { peninsula }\end{array}$ & $\begin{array}{l}\text { Iberian } \\
\text { peninsula }\end{array}$ & \\
\hline \multirow[t]{3}{*}{ Q. robur } & & + & + & + & Groundwater influence \\
\hline & Q. pedunculiflora & + & & & Mediterranean influence \\
\hline & Q. robur ssp. slavonica & + & & & Optimal water conditions \\
\hline \multirow[t]{3}{*}{ Q. petraea } & & + & + & + & Atmospheric humidity \\
\hline & Q. dalechampii & + & & & Tolerance to continental effects \\
\hline & Q. polycarpa & + & & & Tolerance to Mediterranean effects \\
\hline$Q$. frainetto & & + & + & & Tolerance to aridity \\
\hline \multirow[t]{2}{*}{ Q. pubescens } & & + & + & + & (sub)Mediterranean climate, poor soils \\
\hline & Q. virgiliana & + & + & & Tolerance to mesophilous conditions \\
\hline
\end{tabular}

\section{Introduction}

The modern distribution of plant and animal taxa is determined by the current environment, but also by historic events such as the last glacial period (Hengeveld, 1989). Given their importance as glacial refugia (Bennett et al., 1991), it should, therefore, come as no surprise that the three southern European peninsulas (Iberia, Italy and the Balkans) contain such a large fraction of Europe's biodiversity. For instance, all 20 oak species described for Europe in the Atlas Flora Europaea are represented in at least one of the three peninsulas (Jalas and Suominen, 1976). A total of 11 oak species occur in Iberia, 13 in Italy and 12 in the Balkans, including seven, four and six species, respectively, belonging to the Robur (white oak) group
(Nixon, 1993). The most important oak taxa of the Robur group present in the Carpathian Basin and the northern part of the Balkan peninsula are listed in Table 1. In oaks, molecular genetic investigations based on the maternally inherited cpDNA genome (Dumolin et al., 1995) have shown the importance of the two other peninsulas (Italy and Iberia) as glacial refugia and as source of genetic diversity (Fineschi et al., 2002; Olalde et al., 2002; Petit et al., 2002a,b). It was also possible to identify the routes of recolonisation out of these peninsulas. To date, however, few data on oak cpDNA variation exist for the Balkans and the neighbouring regions, with the exception of some oak populations from Bosnia-Herzegovina, Croatia, Hungary, Romania, Slovenia or Slovakia included in the study of Dumolin-Lapègue et al. (1997) (Table 2).

Table 2

Number of individuals (and populations) sampled per country and laboratory of analysis

\begin{tabular}{|c|c|c|c|c|c|c|}
\hline \multirow[t]{2}{*}{ Country } & \multicolumn{5}{|c|}{ Laboratory $^{\mathrm{a}}$} & \multirow[t]{2}{*}{ Total } \\
\hline & 1.1 & 1.2 & 2 & 3 & 4 & \\
\hline Austria (eastern part) & $12(3)$ & & $84(23)$ & $10(2)$ & & $106(28)$ \\
\hline Bosnia-Herzegovina & & & & $15(3)$ & & $15(3)$ \\
\hline Croatia & $3(1)$ & $169(37)$ & & & & $172(38)$ \\
\hline Hungary & $25(3)$ & & & & $262(53)$ & $287(56)$ \\
\hline Rumania & $40(6)$ & $327(68)$ & & & & $367(74)$ \\
\hline Slovakia & $17(3)$ & & & $123(13)$ & & $140(16)$ \\
\hline Slovenia & $9(2)$ & & & & & $9(2)$ \\
\hline Yugoslavia & $12(4)$ & $5(1)$ & & & & $17(5)$ \\
\hline Total & $118(22)$ & $501(106)$ & $84(23)$ & $148(18)$ & $262(53)$ & $1113(222)$ \\
\hline
\end{tabular}

${ }^{a}$ 1.1: INRA laboratory (Dumolin-Lapègue et al., 1997); 1.2: INRA laboratory (this study); 2: ARCS laboratory (this study); 3: BFH laboratory (this study); 4: NIAQC laboratory (this study). 
This study includes the northern Balkan peninsula, the Carpathian Basin and the Carpathian mountains, i.e. Croatia, Slovenia, the northern part of BosniaHerzegovina and Yugoslavia, eastern Austria, Hungary, Romania and Slovakia. The Balkans can be defined as the region of Europe situated south of a line joining Trieste in Italy with the Danube delta: Croatia, Bosnia-Herzegovina, Yugoslavia, Albania, Macedonia, Bulgaria and Greece, as well as the southern part of Romania belong to the peninsula. To the north, the Carpathian Basin is a lowland surrounded by high mountain chains: the Alps, the Carpathians and the Dinarians. The Carpathian Basin is influenced by the continental (steppic) climate of the eastern European plains, which is characterised by hot summers, cold winters and medium precipitation, and also by the Mediterranean climate, characterised by hot, dry summers and mild, rainy winters.

Within this region, four oak species belonging to the Robur group (Quercus robur, Quercus petraea, Quercus pubescens and Quercus frainetto) occur naturally (Table 1). Out of these, the pedunculate oak $(Q$. robur $)$ has been affected the most by the action of man, including seed transfers, artificial regeneration, and selective cutting. In several parts of Europe, and especially in Croatia, Hungary, and eastern Austria, pedunculate oaks of Slavonian origin have been extensively planted since the end of the last century. The Slavonian oak ( $Q$. robur ssp. slavonica) can be distinguished by its exceptionally straight stem, its relatively regular crown and upward pointing branches and both early- and late-flushing characters (Gračan, 1993; Bordács, 1994). The related taxon $Q$. pedunculiflora has been previously considered as a subspecies of $Q$. robur (see reference in Bussoti and Grossoni, 1997). The natural range of this steppic taxon goes from northern Greece to Bulgaria and Romania, and continues further east. It has been described occasionally outside the Balkans, in central Europe (e.g., in Slovakia: Magic, 1975, or in Hungary: Mátyás, 1967). Sessile oak (Q. petraea) has been subdivided in several taxa whose status is still unclear. $Q$. petraea sensu stricto is often mixed with hornbeam (Carpinus betulus) and beech (Fagus sylvatica) on cooler mountain slopes with sufficient atmospheric humidity. $Q$. dalechampii occurs on southern slopes, often associated with $Q$. cerris. This species reaches the northern limit of its distribution in Hungary,
Slovakia and East-Austria. Q. polycarpa is also an oak taxon with more Mediterranean affinities. Its ecology resembles that of pubescent oak, and it is often found mixed with other oak species. Pubescent oaks inhabit the drier, calcareous mountain slopes. The oak forests on these sites were often replaced by vineyards and orchards in the Middle Age. Q. pubescens and the related $Q$. virgiliana are, however, very valuable species because of their tolerance of arid conditions. Hungarian oak $(Q$. frainetto) populations are located primarily in the Southern Carpathians and to the south. Only a few populations in the Basin are likely to be autochthonous. During the last century and at the beginning of the twentieth century, Hungarian oak has been occasionally planted in this region because of its attractive crown and appearance.

In this study, levels of cpDNA diversity and its partitioning among populations will be compared among the investigated white oak species. In addition, the distribution of the haplotypes in the region will be described in order to identify possible primary or secondary refugia and postglacial colonisation routes.

\section{Material and methods}

\subsection{Plant material}

A total of 222 oak populations (1113 individual trees) were sampled in the following countries: Austria, Bosnia-Herzegovina, Croatia, Hungary, Romania, Slovakia, Slovenia and Yugoslavia (Table 2, Fig. 1). Collection guidelines were described in Petit et al. (2002a) for populations collected in forests. Some of this material has been analysed previously (22 populations), and the results published in DumolinLapègue et al. (1997). Material from a $Q$. robur provenance test was used in addition to direct sampling in Croatia (16 of the 38 populations; Gračan, 1993). In general, the aim of the sampling was the collection of all species of the Robur group locally present, however, in Croatia, special emphasis was given to $Q$. robur. In Hungary, some solitary, very old trees were sampled in addition to the regular sampling of populations. These were mostly located in the Great Hungarian Plain, where they may represent the remnants of the forest-steppe. In eastern Austria, oak forests presumed to be natural are restricted to 


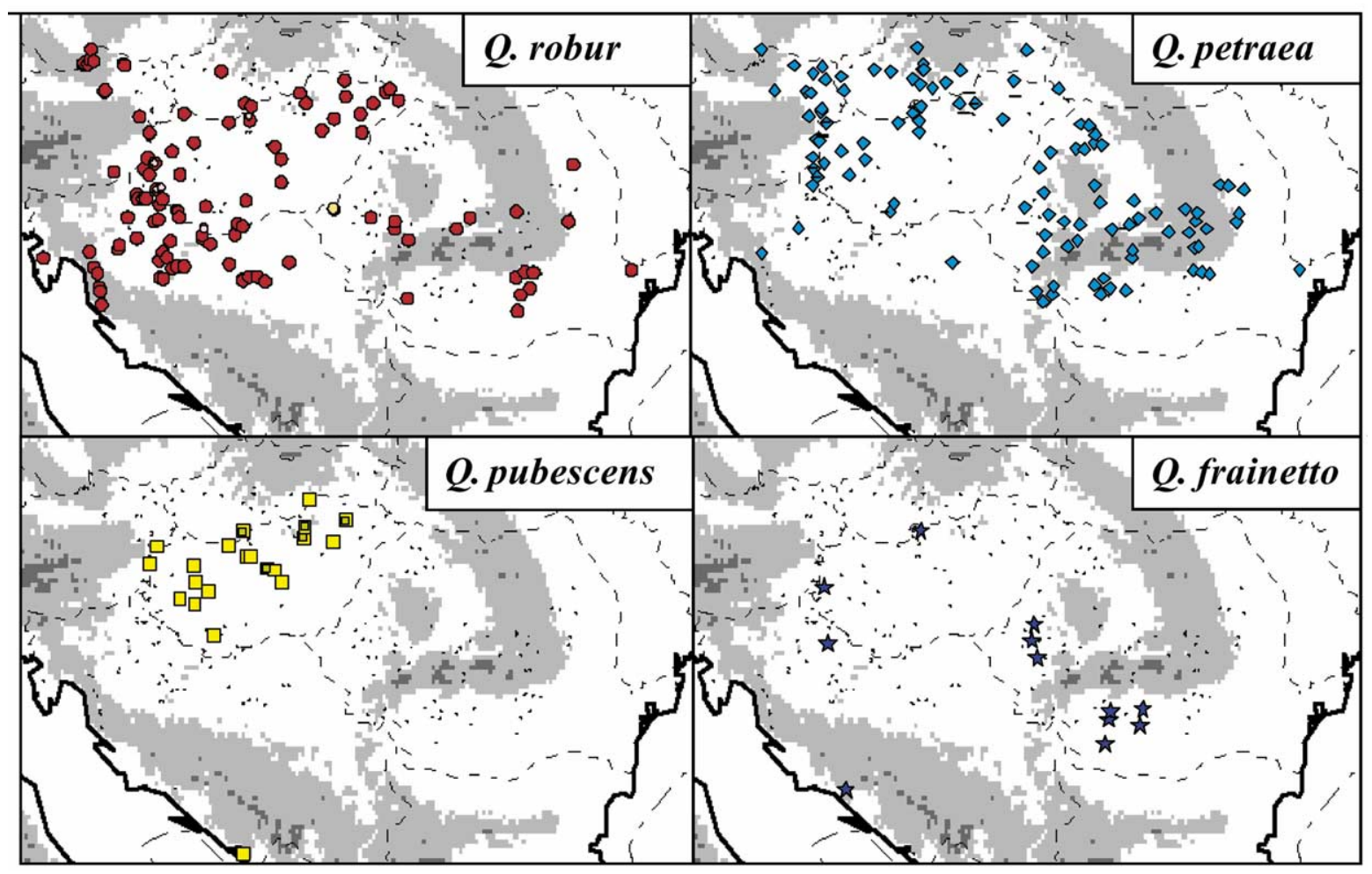

Fig. 1. Distribution of the oak populations investigated for each species or subspecies included. Regions above 500 and $1000 \mathrm{~m}$ are represented by different shades of greys. Those populations identified as belonging to particular subspecies are represented by different colours. For $Q$. robur, the subspecies pedunculiflora is in yellow, the subspecies slavonica in pink; for $Q$. petraea and $Q$. pubescens, the subspecies are dalechampii (dark blue) and virgiliana (dark yellow), respectively.

small areas. Up until the second world war, oaks were felled from all easily accessible forests, and these areas were subsequently replanted with pines. The sample, therefore, consists of the few forests that have escaped this intensive deforestation, or of single trees that appear to be growing again in these pine plantations.

The following species are represented in the present survey: $Q$. robur L. (112 populations), $Q$. petraea (Matt.) Liebl. (116 populations), Q. pubescens Willd. (23 populations), and $Q$. frainetto Ten. (12 populations) (Table 3). Taxonomic identification was based on morphological characters following Mátyás (1970) and Bussoti and Grossoni (1997), and follows partly that of Atlas Flora Europaea, except that Q. pedunculiflora was not considered as a separate species and pooled with $Q$. robur (Jalas and Suominen, 1976). For diversity analyses, only those taxa that are well described and easily distinguishable were included. In particular, trees labelled as $Q$. pedunculiflora in Romania were grouped with $Q$. robur, those named $Q$. dalechampii and $Q$. polycarpa in Hungary were grouped with trees identified as $Q$. petraea and those named $Q$. virgiliana were combined with $Q$. pubescens. Some Slavonian oak stands planted in Hungary and Austria were also sampled, but for diversity analysis they were classified as $Q$. robur.

\section{2. $P C R-R F L P$ procedure}

Samples were processed in four different laboratories: INRA-Bordeaux (France), ARCS (Austria), OMMI (Hungary) and BFH (Germany). The distribution of samples for analysis is shown in Table 2. Methods follow those of Dumolin-Lapègue et al. (1997), with some modifications. For DNA isolation, 
Table 3

Number of individuals sampled per species

\begin{tabular}{|c|c|c|c|c|c|c|c|c|c|c|c|c|c|c|}
\hline & \multicolumn{12}{|c|}{ Haplotype (lineage) } & \multirow{2}{*}{$\begin{array}{l}\text { Total } \\
(3)\end{array}$} & \multirow[t]{2}{*}{$\%$} \\
\hline & $\begin{array}{l}1 \\
\text { (C) }\end{array}$ & $\begin{array}{l}2 \\
\text { (C) }\end{array}$ & $\begin{array}{l}4 \\
\text { (A) }\end{array}$ & $\begin{array}{l}5 \\
\text { (A) }\end{array}$ & $\begin{array}{l}6 \\
\text { (A) }\end{array}$ & $\begin{array}{l}7 \\
\text { (A) }\end{array}$ & $\begin{array}{l}13 \\
(\mathrm{E})\end{array}$ & $\begin{array}{l}15 \\
(\mathrm{E})\end{array}$ & $\begin{array}{l}16 \\
(E)\end{array}$ & $\begin{array}{l}17 \\
(\mathrm{E})\end{array}$ & $\begin{array}{l}30 \\
\text { (A) }\end{array}$ & $\begin{array}{l}31 \\
\text { (A) }\end{array}$ & & \\
\hline Q. robur & 6 & 59 & 14 & 168 & 33 & 96 & 3 & 22 & & 20 & & 13 & 434 & 38.9 \\
\hline Q. robur ssp. slavonica & & & 3 & 7 & & 6 & & & & & & & 16 & 1.4 \\
\hline Q. robur ssp. pedunculiflora & & & & 5 & & & & & & & & & 5 & 0.4 \\
\hline Q. petraea & 2 & 59 & 45 & 200 & 44 & 65 & 14 & 52 & 7 & 41 & 1 & 3 & 533 & 47.9 \\
\hline$Q$. petraea ssp. dalechampii & & & 2 & 3 & & 3 & & & & 7 & & & 15 & 1.3 \\
\hline$Q$. pubescens & & 14 & 9 & 10 & 16 & 18 & & & & 6 & & & 73 & 6.6 \\
\hline Q. pubescens ssp. virgiliana & & 3 & & 2 & 5 & 1 & & & & 1 & & & 12 & 1.1 \\
\hline Q. frainetto & & & & 16 & 18 & 1 & 4 & 2 & 8 & 2 & 4 & & 55 & 4.9 \\
\hline Total $^{\mathrm{a}}$ & 8 & 133 & 68 & 397 & 120 & 183 & 21 & 76 & 15 & 71 & 5 & 16 & 1113 & 100.0 \\
\hline Percentage & 0.7 & 11.9 & 6.1 & 35.7 & 10.8 & 16.4 & 1.9 & 6.8 & 1.3 & 6.4 & 0.4 & 1.4 & 100.0 & \\
\hline
\end{tabular}

a The total includes the four major species (the total for each subspecies is included already in the corresponding species' total) plus those trees which could not be identified to the species status (not shown).

the methods either followed that of Dumolin et al. (1995) based on CTAB, or the QIAGEN plant DNA kit was used. Four largely non-coding cpDNA fragments were studied, each with one restriction enzyme: $\operatorname{trn} \mathrm{D} /$ trnT (DT) with TaqI, psaA/trnS (AS) with HinfI, $p s b \mathrm{C} / t r n \mathrm{D}(\mathrm{CD})$ with $T a q \mathrm{I}$, and $\operatorname{trn} \mathrm{T} / \operatorname{trn} \mathrm{F}(\mathrm{TF})$. Two alternative restriction enzymes were used in the analysis of fragment TF: AluI was used in analyses made in Austria (Austrian and Hungarian populations), whereas HinfI was used for analyses made in France, Hungary and in Germany. The restriction fragments were separated by electrophoresis on $8 \%$ polyacrylamide gels as described in Dumolin et al. (1995), or in higher resolution systems (Csaikl et al., 2002).

\subsection{Genetic diversity analysis}

The frequencies of the haplotypes as well as the distances between them (number of different restriction fragments) were used to compute diversity and differentiation measures, following Pons and Petit (1996) and Petit et al. (2002a). The program HAPLONST and HAPERMUT, available at http:// www.pierroton.inra.fr/genetics/labo/Software, were used. All measures of diversity as well as their standard errors were computed both by taking the distance between haplotypes into account (diversity measure $v$ ) and by ignoring genetic distance (diversity measure h) (Pons and Petit, 1996). The resulting coefficients of differentiation are called $N_{\mathrm{ST}}$ (when based on $v$ ) and $G_{\mathrm{ST}}$ (when using $h$ ), and can be directly compared and their difference tested against zero by permutation analysis (Burban et al., 1999). A total of 1000 permutations of haplotype identity were made; $N_{\mathrm{ST}}$ was re-computed and the proportion of tests where the new value was larger than the direct measure was counted (one-sided test). This procedure is akin to testing whether $N_{\mathrm{ST}}>G_{\mathrm{ST}}$, because through permutation of haplotype identities all distances between haplotypes become equivalent, and the mean $N_{\mathrm{ST}}$ after permutations is equal to the observed $G_{\mathrm{ST}}$. Analyses were made simultaneously for all individuals regardless of species and also separately for each species. All populations considered to be introduced or of dubious origin were eliminated from these analyses as well as those for which sample size was lower than three individuals.

\section{Results}

\section{1. cpDNA polymorphisms}

A total of 12 haplotypes were detected in this survey, two of which were detected for the first time: haplotypes 30 and 31, both belonging to lineage $\mathrm{A}$ and occurring in Romania. All the haplotypes and lineages 
detected, including the two new ones, are described in Petit et al. (2002a), and the designation conforms with that given in this paper, as well as with that of Dumolin-Lapègue et al. (1997). Haplotype 31 is related to haplotype 6 , whereas haplotype 30 is more divergent within the A lineage (Figs. 1 and 2 in Petit et al., 2002a). Other polymorphisms had also been detected in Austria and Hungary, but are not discussed here, as they could be only distinguished with higher resolution and would have gone unrecognised with the experimental conditions used in France or Germany. The most abundant haplotype (No. 5) represents $36 \%$ of all haplotypes. Six other haplotypes have intermediate frequencies (6-16\%) (No. 2, 4, 6, 7, 15 and 17), whereas five are rare $(0.5-2 \%)$ (No. 1, 13, 16, 30 and 31) (Table 3).

\subsection{Partitioning of cpDNA diversity}

The overall mean coefficient of differentiation $G_{\mathrm{ST}}$ is 0.76 , i.e., the majority of cpDNA diversity is distributed among populations (Table 4). Similar results were obtained for the four species when studied separately, with $G_{\mathrm{ST}}$ varying from 0.70 in $Q$. robur to 0.88 in $Q$. pubescens. The ranking is as follows: $Q$. robur $<Q$. petraea $<Q$. frainetto $<Q$. pubescens, with $G_{\mathrm{ST}}$ from $Q$. robur being significantly different from that of $Q$. petraea and $Q$. pubescens $(P<0.05)$. The measures of differentiation that take into account the similarities between haplotypes $\left(N_{\mathrm{ST}}\right)$ give results similar to that of $G_{\mathrm{ST}}$, except that $Q$. frainetto takes the largest value. Again, $N_{\mathrm{ST}}$ is lowest for $Q$. robur, the difference being significant between this species and $Q$. petraea and $Q$. frainetto $(P<0.01)$. In all four cases, $N_{\mathrm{ST}}$ values are slightly higher than the corresponding $G_{\mathrm{ST}}$ values for the same species, significantly so for $Q$. frainetto $(P=0.048)$ and especially for $Q$. petraea $(P<0.0005)$. Furthermore, the overall value (all species included) is also significant $(P=0.019)$.

\subsection{Distribution of haplotypes across species}

Four different oak species are represented in the samples. $Q$. petraea sensu lato and $Q$. robur sensu lato are the most frequent (48.7 and $39.7 \%$ of all trees investigated) (Table 2). $Q$. pubescens sensu lato is represented by $6.7 \%$ of all trees, and $Q$. frainetto by
$5.0 \%$. For three of these species, additional taxa (considered as separate species or as subspecies, depending on the authors) were distinguished, in Hungary, Austria and Romania (Table 1). Note that these subspecies were probably represented in the samples from the other countries, but have not been differentiated, therefore, only the main taxa (sensu lato) were used for the diversity analysis.

Interestingly, no species specific haplotype was found. All haplotypes are shared by at least two species, even the rarest one (haplotype 30) (Table 3). The most frequent haplotypes (No. 5, 6, 7 and 17) were present in all taxa investigated here.

\subsection{Geographic distribution of the haplotypes}

The distribution of each of the 12 haplotypes is given in Fig. 2, and appears structured: the distribution of several of the haplotypes do not overlap at all. Haplotype 1 is present only in eastern Austria, in four populations. Haplotype 2 has also a very restricted range in the western part of the region investigated here: it is found on the northern Croatian coast, and across northern Croatia and western Hungary, and reaches western Slovakia and eastern Austria. Similarly, the distribution of haplotype 4 is strongly clustered, but as two distinct patches, one in southern Slovakia and northern Hungary, the other south of the southern Carpathian mountain ranges, in the region of Bucharest. The more frequent haplotype 5 has a larger distribution and can be found throughout the Carpathian Basin. It is, however, rare south of the Carpathian mountains in Romania, and then is often found in mixed-haplotype population. Though less frequent, the distribution of haplotype 6 is very similar to that of haplotype 5, except that it is quite rare in the west of Hungary and absent from western Croatia. In contrast, the distribution of haplotype 7 is centred further west, from northern Croatia to western Hungary and western Slovakia to Austria. It was detected in a couple of populations from Romania, but by a single individual in both cases, mixed with individuals characterised by other haplotypes. Three of the four haplotypes of lineage E (13, 15 and 16) have a very similar distribution in the southern half of Romania, but are not present (except for two mixed populations in the case of haplotype 15) in the Carpathian Basin or further west. The fourth 
Table 4

Levels of diversity and differentiation by species

\begin{tabular}{|c|c|c|c|c|c|c|c|c|}
\hline & $\begin{array}{l}\text { Number of } \\
\text { populations } \\
(\geq 3 \text { individuals) }\end{array}$ & $\begin{array}{l}\text { Harmonic mean } \\
\text { number of individuals } \\
\text { per population }\end{array}$ & $\begin{array}{l}\text { Number of } \\
\text { haplotypes }\end{array}$ & $\begin{array}{l}h_{\mathrm{S}} \\
\text { (standard error) }\end{array}$ & $\begin{array}{l}h_{\mathrm{T}} \\
\text { (standard error) }\end{array}$ & $\begin{array}{l}G_{\mathrm{ST}} \\
\text { (standard error) }\end{array}$ & $\begin{array}{l}N_{\mathrm{ST}} \\
\text { (standard error) }\end{array}$ & $\begin{array}{l}\text { Proportion of } \\
\text { permutation tests } \\
\text { where } N_{\mathrm{ST}}>G_{\mathrm{ST}}\end{array}$ \\
\hline Q. robur & 88 & 4.18 & 10 & $0.233(0.032)$ & $0.779(0.026)$ & $0.700(0.041) \mathrm{a}$ & $0.720(0.050) \mathrm{a}$ & $0.251(\mathrm{NS})^{\mathrm{a}}$ \\
\hline Q. petraea & 98 & 4.59 & 11 & $0.142(0.025)$ & $0.799(0.029)$ & $0.820(0.033) \mathrm{b}$ & $0.883(0.025) \mathrm{b}$ & $0.000^{* * *}$ \\
\hline Q. pubescens & 13 & 3.94 & 6 & $0.103(0.069)$ & $0.858(0.039)$ & $0.880(0.082) \mathrm{b}$ & $0.895(0.084) \mathrm{ab}$ & 0.380 (NS) \\
\hline Q. frainetto & 11 & 4.78 & 7 & $0.136(0.072)$ & $0.828(0.062)$ & $0.835(0.083) \mathrm{ab}$ & $0.905(0.053) \mathrm{b}$ & $0.048^{*}$ \\
\hline All species & 203 & 4.83 & 12 & $0.193(0.020)$ & $0.801(0.034)$ & $0.758(0.025)$ & $0.794(0.027)$ & $0.019^{*}$ \\
\hline
\end{tabular}

${ }^{\text {a }}$ Not significant.

${ }^{*} P<0.05$.

${ }^{* *} P<0.01$. 


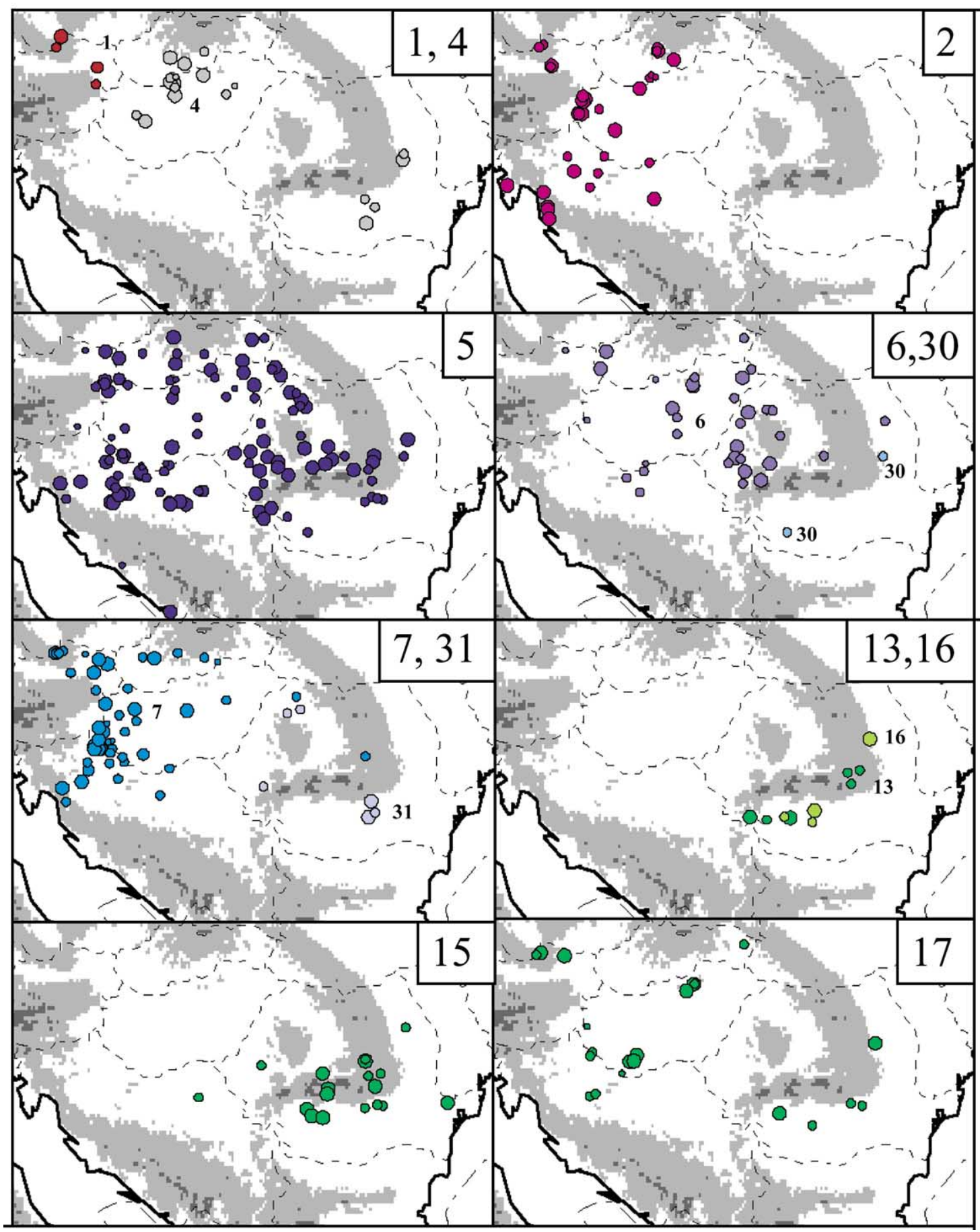

Fig. 2. Distribution of each of the 12 haplotypes detected during the survey. Regions above 500 and $1000 \mathrm{~m}$ are represented by different shades of greys. Symbol sizes are roughly proportional to the likeliness that the population is autochthonous: populations fixed for a given haplotype are represented by the larger circles, those of dubious status by the smaller ones, and those populations where more than one haplotype have been identified are represented by intermediate symbols. Colours of haplotypes are as in Petit et al. (2002a). 
haplotype of lineage E (No. 17), on the contrary, has a disjunct range both in south-eastern Romania and in the Carpathian Basin, as in the case of haplotype 4. However, those haplotypes present south and east of the Romanian Carpathian mountains have a distribution very similar to that of the three other haplotypes of the same lineage, as does haplotype 30 (which is restricted to two populations). The distribution of haplotype 31 is also centred in southern Romania, but was detected in the north-west of the country as well.

\section{Discussion}

\subsection{Comparison of cpDNA diversity between oak species}

The analysis of levels of differentiation across species indicate that $Q$. robur has lower values (as measured by both $G_{\mathrm{ST}}$ and $N_{\mathrm{ST}}$ ) compared to the other species. Other studies similarly point out the lower level of differentiation for $Q$. robur compared to other oaks (Cottrell et al., 2002; Dumolin-Lapègue et al., 1999; Petit et al., 2002a,c). As discussed in Section 1, this species was frequently used in plantations in the last 150 years. In the past, coppicing of sessile and pubescent oak forests was widely practised throughout the area, while plantations of these oak taxa remained rare before the end of the nineteenth century. This could indicate that most populations of $Q$. petraea sensu lato and $Q$. pubescens sensu lato sampled are likely to be autochthonous, because coppicing should preserve the original maternal genetic structure. However, acorns have been used as food for both humans and animals for millennia. In particular, some of the oak 'pasture forests' located in Hungary along the trading routes to Vienna were planted 300-400 years ago to feed cattle (Kolossvary, 1975). Such human influences are more likely to destroy the preexisting genetic structure than to create a new one.

Despite the differences noted in the way species partition cpDNA diversity, they share extensively the same haplotypes, even at the local scale. This finding confirms the results of previous studies in France between $Q$. robur and $Q$. petraea (Petit et al., 1997) or between $Q$. robur, $Q$. petraea, and $Q$. pubescens (Dumolin-Lapègue et al., 1999). It supports the view that introgression was not restricted to rare episodes during long periods of sympatry, for instance in refugia during the last ice age, but also took place during or after recolonisation (Petit et al., 1997).

\subsection{Geographic structure}

Compared to the previous study (Dumolin-Lapègue et al., 1997), the additional sampling of oak populations and cpDNA analyses has resulted in a tenfold increase of the number of samples in the region investigated. A strong geographic structure was revealed, and a deep genetic divide was observed along the Carpathian mountains. Indeed, among the 12 haplotypes detected in the region, five occur mostly or exclusively west of the Eastern and Southern Carpathians (in the Carpathian Basin), four mostly to the east and only three are found on both sides. Haplotypes of lineage $\mathrm{E}$ dominate the east, and haplotypes of lineages $\mathrm{A}$ and $\mathrm{C}$ are more frequent in the west. A phylogeographic structure is, therefore, apparent as shown by the comparison of the two measures of genetic differentiation: $N_{\mathrm{ST}}$ was higher than $G_{\mathrm{ST}}$ in all four species investigated, significantly so in $Q$. frainetto, in Q. petraea and in the total sample. Within the Carpathian Basin, there is also a clear geographic structure, with haplotypes 2, 17 and partly 7 having similar distributions in the west, and haplotypes 5 and 6 being more abundant further east.

\subsection{Secondary refugia and colonisation routes}

Despite these clear geographic patterns, the interpretation of these distributions in terms of refugia and colonisation routes can only be tentative, given the lack of data further south, in Albania, Bulgaria, Greece, or Macedonia, in particular. As discussed in Brewer et al. (2001), oak refugia at the height of the glacial period were probably restricted to the very south of the continent. However, the warming that marked the end of the last glacial period was not a steady phenomenon; in particular, a marked climatic deterioration followed the initial warming phase of the Lateglacial Interstadial: the Younger Dryas, which lasted approximately from 11,000 to 10,000 years before the present. The expansion of oaks was markedly slowed during this period, and many populations may have disappeared at that time. Those populations that survived at the northern edge of the 
distribution, in favourable conditions, must have played an important role in the subsequent recolonisation process at the onset of the Holocene period. Such populations have been called 'secondary refugia' by Brewer et al. (2001) to distinguish them from the 'primary refugia' that hosted oak populations without interruption throughout the last glacial period.

Although the region studied is unlikely to have hosted such primary refugia, being located north of the $42^{\circ} \mathrm{N}$ parallel (Brewer et al., 2001; Petit et al., 2002b), the existence of secondary refugia is quite likely. Indeed, several low or medium mountains in this region could have offered favourable climates during the Younger Dryas period to support viable populations of oak trees. Due to its position immediately at the north of the Balkan region, and the proximity of Italy, to which it was linked by the exposed sea bed of the north Adriatic during the last glacial period and the beginning of the postglacial times (see maps in Petit et al., 2002b), the Carpathian Basin may have acted as a meeting point of several colonisation routes.

The presence of disjunct populations of species, such as Carpinus orientalis in the Vértes mountain in North-Hungary (Gencsi and Vancsura, 1992), which have a distribution otherwise centred to the very southeast part of the Balkan peninsula, suggests an early colonisation from the south-east, perhaps as early as the Lateglacial, with a secondary refugium in the Carpathian Basin. The large number of endemic species existing in the Carpathian Basin and in the Carpathians also supports the importance of this region for the maintenance of diversity. The populations of these species would have found shelter on the southern slopes of the low or middle $(500-1000 \mathrm{~m})$ altitude mountains located sporadically in the Basin (Vértes, Mátra, Bükk, Pilis, etc.), where the solar radiation could mitigate the effect of the cold climate. The dolomite bedrock is quite common in the Carpathian Basin and due to its weathering characters provides sites for (sub)Mediterranean species. Presently, during winter, the cold layer of air often remains for several weeks in the lowlands, while the tops of the higher mountains (over 800-900 m) are exposed to the sun and have above zero temperatures. For details on the 'hill up and down' hypothesis, see Zólyomi (1958), Borhidi (1997) or Bennett (1997). The oak charcoal fossils found in fireplaces of human populations living 11,000-10,000 BP in the Basin (Zólyomi, 1958) add support the hypothesis of secondary refugia in this region. Krippel (1986) has summarised the evidence in favour of the early presence of oaks in Slovakia. Similarly, there are proofs of secondary refugia in Slovenia (Culiberg, 1991; Šercelj, 1996), where occurrences of oak pollen have been found throughout the last glacial period. These expansions are linked to short-lived warming events and may be analogous to the expansion of the oak during the Lateglacial period from a refugium further south (Brewer et al., 2001). Alternatively, Šercelj (1996) argues that these may represent the presence of scattered, continuous tree populations during the glacial period. According to this author, "reliable proof of the permanent though very scattered presence of mesophilic broad-leaved trees is the established fact that pollen from these broad-leaved trees appeared immediately in larger numbers with every warming in the Würm and the late glacial periods. This could mean that individual tree species grew somewhere in the vicinity and, therefore, did not immigrate".

The existence of (secondary) refugia could also explain the disjunct distribution of haplotype 4 , found in the south of Romania, but also in the north of the Carpathian Basin in Hungary and Slovakia, i.e., $470 \mathrm{~km}$ away, in a region of medium high mountains (Mátra, Börzsöny, Pilis, etc.). This haplotype could have had its primary refugium in the south-east Balkans, possibly on the Bulgarian coast of the Black Sea (Brewer et al., 2001), and would have then migrated northward from there during the Lateglacial Interstadial. The impact of the return to cold and arid conditions during the Younger Dryas period would have caused a decline and disappearance of populations located between these two regions, being later replaced by others originating from different refugia and characterised by other haplotypes.

The distribution of haplotype 7 in the studied region, and its absence from most of Italy except the very north (Fineschi et al., 2002), could also indicate the existence of a secondary refugium, on the southern slopes of the mountains of Slovenia, east Austria or Croatia. Trees immigrating from further south would have brought this haplotype in this mountainous region quickly after the onset of postglacial recolonisation. In fact, palynological evidence exist for the continuous presence of oaks in the north-west of Greece during the last glacial period (Tzedakis, 1993). 
Rapid expansion from this secondary refugium at the start of the Holocene period would explain the extensive distribution of oaks characterised by haplotype 7 further north and throughout most of the alpine region (Csaikl et al., 2002; Mátyás and Sperisen, 2001; Petit et al., 2002b). Furthermore, the presence of oak forests harbouring this haplotype may have blocked the progress of haplotype 1 (originating from an Italian refugium, see Fineschi et al., 2002). Indeed, this haplotype is found in eastern Austria, but was unable to migrate further east and south.

Italian glacial refugia have also been proposed for haplotypes 2 and 17, whereas the situation is less clear for haplotype 5, which may have migrated into southern Italy from north-eastern Greece or Albania (Fineschi et al., 2002; Petit et al., 2002b). Movements across the current northern part of the Adriatic have been facilitated by the exposure of the northern Adriatic sea bed until the early Holocene (Thompson and Schweitzer, 1996). The distribution of haplotype 2 in the region studied is particularly indicative of such a migration, as it seems to radiate from the north of the Adriatic. From there, colonisation appears to be parallel to that of haplotype 7 , slightly more eastwards, suggesting a contemporaneous migration. Had the migration of the haplotypes occurred at different times, it may be expected that one of the haplotypes would have dominated the whole region. The migration for haplotype 5 seems to have followed the same path than that of haplotype 2, also perhaps from Italy. The presence of haplotype 5 further east, up to the western part of Romania where it is very abundant, means either that it migrated quicker there from the west, or that it was also present in the Dinarians and moved directly from there into the eastern Carpathian Basin. The fact that the single southern Croatian population analysed so far has this haplotype supports this hypothesis, but additional sampling in the south is requested to confirm it. However, the distribution of haplotype 6 also suggests such a colonisation route further east, along the Bihar Mountains (Romania) and the Southern-Carpathians. Note that haplotype 6 is nearly completely absent from Italy (Fineschi et al., 2002). It may be worth checking further whether haplotype 5 is not composite (Petit et al., 2002a), as it could consist of one or more subvariants, some having a distribution similar to that of haplotype 6 , and others with a distribution resembling that of haplotypes 2 and 7. There are also indications that haplotype 17 could be composite (Petit et al., 2002a). This would explain the disjunction between the five populations east of the Carpathian mountains in Romania, and those situated in the central-western part of the Carpathian Basin. The south-west/northeast orientation of the distribution of haplotypes 2, 6 and 17 in Hungary is quite striking, and indicates that they have followed, at least in part, similar migration routes. The fact that these three haplotypes belong to completely different lineages demonstrates that similar geographic patterns may arise for unrelated haplotypes, provided that their initial distribution is similar. As a consequence, the phylogeographic structure will remain limited to those cases where there is less opportunity for different lineages to mix, because of stronger barriers to migration or the existence of widely separate refugia. This is exactly the situation for haplotypes 13,15 and 16 of the E lineage, which may have originated from a refugium in the south eastern Balkans, for instance along the coast of the Black Sea (Brewer et al., 2001). These haplotypes obviously had difficulties in crossing the Romanian Carpathians, even though many passes below $1000 \mathrm{~m}$ (even below $500 \mathrm{~m}$ ) exist in these mountains. In Switzerland, passes well over $2000 \mathrm{~m}$ appear to have been crossed (Mátyás, 1999; Mátyás and Sperisen, 2001), but the situation may be quite different in the Carpathians, given the more continental climate. For instance, sessile oak populations were reported from 1000 to $1100 \mathrm{~m}$ altitude in the Southern Carpathians (Fekete and Blattny, 1913), whereas populations located at $1400 \mathrm{~m}$ or higher are known in the French Alps. Another (non-exclusive) possibility is that the two colonisation routes met precisely in this region, and that further migration was made difficult by the presence of other oak populations. Altogether, this resulted in a strong phylogeographic structure, with quite similar geographic distributions for the more related haplotypes.

\section{Acknowledgements}

The study has been carried out with financial support from the Commission of the European Communities, Agriculture and Fisheries (FAIR) specific RTD programme, CT-FAIR 1 PL95-0297, "Synthetic 
maps of gene diversity and provenance performance for utilisation and conservation of oak genetic resources in Europe". It does not necessarily reflect its views and in no way anticipates the Commission's future policy in this area. Parts of this study were also supported by the Foundation of Austrian-Hungarian Action (32/OeU5), the National Committee for Technological Development, Hungary (OMFB 01735/98), OTKA Hungary (T 30778), the Direction des Relations Internationales (INRA), the Ministère des Affaires Étrangères and the Centre International des Étudiants et Stagiaires (CIES). We are very grateful to Karin Hohl, Katrin Groppe, Marie-Helène Pemonge, Terézia Kanizsai, István Bach, Zsuzsa Pamuki for helpful assistance in the laboratory, and to Ioan Blada, E.N. Popescu, Ovidiu Iordan, Dan Pepelea, Gheorghe Sarbu, Andrei Dragila, Stefan Tanasie, for collecting oak samples in the field.

\section{References}

Bennett, K.D., 1997. Evolution and ecology. The Pace of Life. Cambridge University Press, Cambridge, $241 \mathrm{pp}$.

Bennett, K.D., Tzedakis, P.C., Willis, K.J., 1991. Quaternary refugia of north European trees. J. Biogeogr. 18, 103-115.

Bordács, S., 1994. Observations of flowering-biology of pedunculate oak (Quercus robur). Erdészeti és Faipari Tudományos Közlemények 40-41, 53-66 (in Hungarian).

Borhidi, A., 1997. Thoughts and doubts: the Ösmátra theory. Studia Phytologica Jubilaria, University of Pécs, pp. 161-188 (in Hungarian).

Brewer, S., Cheddadi, R., de Beaulieu, J.-L., Reille, M., Data contributors, 2001. The spread of deciduous Quercus throughout Europe since the last glacial period. For. Ecol. Manage., this issue.

Burban, C., Petit, R.J., Carcreff, E., Jactel, H., 1999. Rangewide variation of the maritime pine bast scale Matsucoccus feytaudi Duc. (Homoptera: Matsucoccidae) in relation to the genetic structure of its host. Mol. Ecol. 8, 1593-1602.

Bussoti, F., Grossoni, P., 1997. European and Mediterranean oaks (Quercus L.; Fagaceae): SEM characterization of the micromorphology of the abaxial leaf surface. Bot. J. Linn. Soc. 124, 183-199.

Cottrell, J.E., Munro, R.C., Tabbener, H.E., Gillies, A.C.M., Forrest, G.I., Deans, J.D., Lowe, A.J., 2002. Distribution of chloroplast variation in British oaks (Quercus robur and $Q$. petraea): the influence of postglacial recolonization and human management. For. Ecol. Manage. 156, 181-195.

Csaikl, U.M., Burg, K., Fineschi, S., König, A.O., Mátyás, G., Petit, R.J., 2002. Chloroplast DNA variation of white oaks in the Alpine region. For. Ecol. Manage. 156, 131-145.

Culiberg, M., 1991. Late glacial vegetation in Slovenia. Opera Academiae Scientiarum et Artium Slovenicae. Classis IV: Historia Naturalis 29, 1-52.
Dumolin, S., Demesure, B., Petit, R.J., 1995. Inheritance of chloroplast and mitochondrial genomes in pedunculate oak investigated with an efficient PCR method. Theoret. Appl. Genet. 91, 1253-1256.

Dumolin-Lapègue, S., Demesure, B., Le Corre, V., Fineschi, S., Petit, R.J., 1997. Phylogeographic structure of white oaks throughout the European continent. Genetics 146, 14751487.

Dumolin-Lapègue, S., Kremer, A., Petit, R.J., 1999. Are chloroplast and mitochondrial DNA variation species-independent in oaks? Evolution 53, 1406-1413.

Fekete, L., Blattny, T., 1913. Az erdészeti jelentôségü fák és cserjék elterjedése a magyar állam területén (The distribution of forest trees and shrubs in Hungary), Vols. I-II, Selmecbánya, Joerges A. Ny (in Hungarian).

Fineschi, S., Taurchini, D., Grossoni, P., Petit, R.J., Vendramin, G.G., 2002. Chloroplast DNA variation of white oaks in Italy. For. Ecol. Manage. 156, 103-114.

Gencsi, L., Vancsura, R., 1992. Dendrológia. Mezogazda Kiadó, Budapest, 728 pp. (in Hungarian).

Gračan, J., 1993. Preliminary results of common oak (Q. robur L.) provenance experiments in Croatia. Ann. Sci. For. 50 (Suppl.), 215s-221s.

Hengeveld, R., 1989. Dynamics of Biological Invasions. Chapman \& Hall, London.

Jalas, J., Suominen, S., 1976. Atlas Florae Europaeae. 3. Salicaceae to Balanophoraceae. Helsinki. Online Version for 1999. http://www.helsinki.fi/kmus/afe/database.html.

Kolossvary, Sz (Ed.), 1975. Az erdõgazdálkodás története Magyarországon (The history of forestry in Hungary). Akadémiai Kiadó, Budapest (in Hungarian).

Krippel, E., 1986. Postglaciálny Vývoj Vegetácie Slovenska (Postglacial Development of the Vegetation of Slovakia), Veda, Bratislava, 307 pp. (in Slovak).

Magic, D., 1975. Taxonomické poznámky z doterajšieho výskumu dubov v Západných Karpatoch (Taxonomical notes from the up-to-day research of oaks in the Western Carpathians). Biológia (Bratislava) 30, 65-74 (in Slovak).

Mátyás, V., 1967. A tölgyek dendrológiai ismertetése. In: Keresztesi, B. (Ed.), A Tölgyek. Akadémiai Kiadó, Budapest, pp. 51-90 (in Hungarian).

Mátyás, V., 1970. Quercus. In: Soo, R. (Ed.), Synopsis Flora Vegetationisque Hungariae IV. Akadémiai Kiadó, Budapest, pp. 507-540 (in Hungarian).

Mátyás, G., 1999. Rekonstruktion der nacheiszeitlichen Einwanderung der Eichen in der Schweiz anhand ihrer ChloroplastenDNA. Thesis. Diss. Nr. 13386, ETH Zürich, Switzerland.

Mátyás, G., Sperisen, C., 2001. Chloroplast DNA polymorphisms provide evidence for postglacial recolonization of oaks (Quercus spp.) across the Swiss Alps. Theoret. Appl. Genet. $112,12-20$.

Nixon, K.C., 1993. Infrageneric classification of Quercus (Fagaceae) and typification of sectional names. Ann. Sci. For. 50 (Suppl.), s25-s34.

Olalde, M., Herrán, A., Espinel, S., Goicoechea, P.G., 2002. White oaks phylogeography in the Iberian peninsula. For. Ecol. Manage. 156, 89-102. 
Petit, R.J., Pineau, E., Demesure, B., Bacilieri, R., Ducousso, A., Kremer, A., 1997. Chloroplast DNA footprints of postglacial recolonization by oaks. Proc. Natl. Acad. Sci. USA 94, 999610001.

Petit, R.J., Csaikl, U.M., Bordács, S., Burg, K., Coart, E., Cottrell, J., van Dam, B.C., Deans, J.D., Dumolin-Lapègue, S., Fineschi, S., Finkelday, R., Gillies, A., Glaz, I., Goicoechea, P.G., Jensen, J.S., König, A., Lowe, A.J., Madsen, S.F., Mátyás, G., Munro, R.C., Olalde, M., Pemonge, M.-H., Popescu, F., Slade, D., Tabbener, H., Taurchini, D., de Vries, S.M.G., Ziegenhagen, B., Kremer, A., 2002a. Chloroplast DNA variation in European white oaks: phylogeography and patterns of diversity based on data from over 2600 populations. For. Ecol. Manage. 156, 5-26.

Petit, R.J., Brewer, S., Bordács, S., Burg, K., Cheddadi, R., Coart, E., Cottrell, J., Csaikl, U.M., van Dam, B.C., Deans, J.D., Espinel, S., Fineschi, S., Finkeldey, R., Glaz, I., Goicoechea, P.G., Jensen, J.S., König, A.O., Lowe, A.J., Madsen, S.F., Mátyás, G., Munro, R.C., Popescu, F., Slade, D., Tabbener, H., de Vries, S.M.G., Ziegenhagen, B., de Beaulieu, J.-L., Kremer, A., 2002b. Identification of refugia and postglacial colonization routes of European white oaks based on chloroplast DNA and fossil pollen evidence. For. Ecol. Manage. 156, 49-74.

Petit, R.J., Latouche-Hallé, C., Pemonge, M.-H., Kremer, A., 2002c. Chloroplast DNA variation of oaks in France and the influence of forest fragmentation on genetic diversity. For. Ecol. Manage. 156, 115-129.

Pons, O., Petit, R.J., 1996. Measuring and testing genetic differentiation with ordered versus unordered alleles. Genetics 144, 1237-1245.

Šrcelj, A., 1996. The origins and development of forests in Slovenia. Opera Academiae Scientiarum et Artium Slovenicae. Classis IV: Historia Naturalis 35, 81-142.

Thompson, R.S., Schweitzer, P.N., 1996. Global gridded Pliocene and Quaternary sea-level. US Geological Survey Open-File Report 96-000. http://geochange.er.usgs.gov/pub/sea_level/

Tzedakis, P.C., 1993. Long-term tree populations in north west Greece through multiple quaternary cycles. Nature 364, 437-440.

Zólyomi, B., 1958. The natural vegetation of Budapest's environs. In: Pécsy, M. (Ed.), Budapest Természeti Képe. Akadémiai Kiadó, Budapest, pp. 509-642 (in Hungarian). 